\title{
Type I Hair Cell
}

National Cancer Institute

\section{Source}

National Cancer Institute. Type I Hair Cell. NCI Thesaurus. Code C12630.

A flask-shaped mechanoreceptor cell that detects and transduces head movements into neural impulses and is located within the vestibular and auditory systems of mammals, birds, and reptiles. 